UDC 94(477.83/.86)“1914/1917"

DOI: $10.24919 / 2519-058 x .16 .210900$

\title{
Svitlana ORLYK
}

PhD hab. (History), Professor, Professor of Department of History, Archeology, Informational and Archival Affairs at Central Ukrainian National Technical University, 8 Prospekt Universytetsky,Kropyvnytskyi, Ukraine, pastal code 25006 (svitlana.orlik@gmail.com)

ORCID: http://orcid.org/0000-0002-6280-9273

Researcher ID: C-1033-2019 (http://www.researcherid.com/rid/C-1033-2019)

\section{Alina MEKHEDA}

PhD (Education), Department of History, Archeology, Informational and Archival Affairs at Central Ukrainian National Technical University, 8 Prospekt Universytetsky, Kropyvnytskyi, Ukraine, pastal code 25006 (wiatr.cieply@gmail.com)

ORCID: https://orcid.org/0000-0001-5660-512X

Researcher ID: https://publons.com/researcher/2915789/alina-mekheda/

\section{Світлана ОРЛИК}

докторка історичних наук, професорка, професорка кафедри історії, археології, інформаиійної та архівної справи Центральноукраїнського національного технічного університеmy, nр. Університетський, 8, м. Кропивницький, 25006, Украӥна (svitlana.orlik@gmail.com)

\begin{abstract}
Аліна МЕХЕДА
кандидатка педагогічних наук, старша викладачка кафедри історії, археології, інформаційної та архівної справи Центральноукрайнського технічного університету, пр.Університетський, 8, м. Кропивниџький, 25006, Украӥна (wiatr.cieply@gmail.com)
\end{abstract}

Бібліографічний опис статті: Orlyk, S. \& Mekheda, A. (2020). Natural duties of the population of Eastern Galicia and Northern Bukovyna under conditions of the Russian occupation (1914 - 1917). Skhidnoievropeiskyi istorychnyi visnyk [East European Historical Bulletin], 16, 153-162. doi: 10.24919/2519-058x.16.210900

\section{NATURAL DUTIES OF THE POPULATION OF EASTERN GALICIA AND NORTHERN BUKOVYNA UNDER CONDITIONS OF THE RUSSIAN OCCUPATION (1914 - 1917)}

\begin{abstract}
The purpose of the article is to study the mechanism of establishment and organization of natural duties by the Russian occupation authorities in the occupied territories of Eastern Galicia and Northern Bukovyna during World War I and the attitude of the local population to the problem of performing these natural duties. The methodological basis of a scientific research is a set of general scientific and special research methods. Special historical methods characteristic of socio-economic history have been widely used: historical-comparative, retrospective, diachronic (periodization), historical-systemic, historical-typological, historical-genetic and the method of a historical economic analysis. The scientific novelty of the study consists in the following: for the first time in historiography on the materials of the archival documents, introduced by the author into a scientific circulation, there has been analysed the mechanism of natural duties (labour duties), organized by the Russian occupation
\end{abstract}


authorities in the occupied territories of Eastern Galicia and Northern Bukovyna during World War I. The Conclusions. Thus, the natural duties imposed by the Russian occupation authorities during World War I were a heavy burden to the local population of Eastern Galicia and Northern Bukovyna, bankrupt and devastated by war. The natural duties were one of the elements of the financial policy of the countryoccupant. Extremely difficult, especially for women and adolescents, were the natural duties in the form of trench work, deforestation, restoration of rail and land routes, etc. The natural duties were extremely difficult for livestock owners, as a result of which the local population was forced to get rid of horses, which negatively affected the quality of agricultural work and worsened the level of food supply in the region. At the same time, the Russian occupation authorities practised paying low salary, which was not even always paid. The performance of the natural duties by the local population was coercive, which was exacerbated by the imposition of severe liability in the form of high fines or imprisonment (arrest). At the same time, it was advantageous for the occupation authorities to exploit the local population, because during the war the exploitation allowed them to save significant financial resources.

Having done a comparative analysis of the occupation authorities actions, established in the lands of Eastern Galicia and Northern Bukovyna, - the Russian occupation authorities (during World War I) and the German occupation authorities (during World War II), we concluded that in both cases the local population was subjected to severe coercion measures and had to work in the interests of the occupation military forces and civilian authorities. According to the author, the whole set of the natural duties should be divided into two groups, taking into account the peculiarities of establishment: military occupation natural duties, civil occupation natural duties. In general, under conditions of both world wars, the process of introduction of natural duties for the needs of both the army and the civilian occupation authorities by the conquering countries - the Russian Empire and the Nazi Germany - was characterized by many common features. Therefore, further research requires the establishment and collection of taxes, fees and other non-tax payments from the population of Western Ukraine by various occupation regimes during the First and Second World War I and World War II. In our opinion, a comparative analysis of these problems will be especially important and perspective for scientific consideration.

Key words: World War I, World War II, Eastern Galicia, Bukovyna, the Russian Empire, GaliciaBukovyna Military Governor-General, the Russian occupation, natural duties.

\section{НАТУРАЛЬНІ ПОВИННОСТІ НАСЕЛЕННЯ СХІДНОЇ ГАЛИЧИНИ ТА ПІВНІЧНОЇ БУКОВИНИ В УМОВАХ РОСІЙСЬКОЇ ОКУПАЦІЇ (1914 - 1917)}

\footnotetext{
Анотація. Метою статті є дослідження механізму встановлення та стягнення російською окупаційною владою натуральних повинностей на захоплених територіях Східної Галичини та Північної Буковини в роки Першої світової війни. Методологічну основу наукового пошуку становить сукупність загальнонаукових і спеціальних методів дослідження. Широко використовувалися спеціальні історичні методи, характерні для сочіально-економічної історії: історико-порівняльний, ретроспективний, діахронний (періодизаиії), історико-системний, історико-типологічний, історико-генетичний і метод історико-економічного аналізу. Наукова новизна дослідження полягає у тому, що вперше в історіографії на матеріалах архівних документів, які вводяться автором до наукового обігу, розглянуто механізм стягнення російською окупаиійною владою натуральних повинностей на захоплених територіях Східної Галичини та Північної Буковини в роки Першої світової війни. Висновки. Натуральні повинності, які стягувалися російською окупаиійною владою в роки Першої світової війни, лягали важким тягарем на розорене війною місиеве населення Східної Галичини та Північної Буковини. Надзвичайно тяжкими, особливо для жінок і підлітків, були натуральні повинності у вигляді окопних робіт, вирубки лісу, відбудови залізничних та сухопутних доріг тощо. Вкрай обтяжливою була підводна повинність, внаслідок впровадження якої місиеве населення було змушене позбуватися тяглової сили, що негативно впливало на якість виконання сільськогосподарських робіт та погіршувало рівень продовольчого забезпечення регіону. Виконання натуральних повинностей мало примусовий характер і супроводжувалося встановленням суворої відповідальності у вигляді високих грошових штрафів або позбавлення волі (арешту). Окупаційній владі було вигідно експлуатувати місиеве населення, адже ие дозволяло їй економити значні фінансові ресурси.

У результаті проведеного порівняльного аналізу поведінки окупаційних влад, які встановлювалися на землях Східної Галичини та Північної Буковини, - російської (в роки Першої світової
} 
війни) та німецької (під час Другої світової війни) - з урахуванням особливостей встановлення і стягнення натуральних повинностей запропоновано увесь комплекс натуральних повинностей розділити на дві групи: військово-окупаційні та иивільно-окупаційні. Доведено, щзо під час обох світових воєн у процесі запровадження натуральних повинностей як для потреб армії, так $i$ для циивільної окупаційної влади політика країн-завойовниць - Російської імперії та нацистської Німеччини - на окупованих територіях мала багато спільних рис, зумовлених закономірним у такій ситуації протистоянням окупаиійної влади та місиевого населення.

Ключові слова: Перша світова війна, Друга світова війна, Східна Галичина, Буковина, Російська імперія, Галиџько-Буковинське військове генерал-губернаторство, російська окупаџія, натуральна повинність.

The Problem Statement. During the world wars, when the enemy's territories were in the rear of the conquering countries, the latter without any delay tried to establish their own civilian occupation authority in order to maximize the consolidation of their positions in these lands. However, among the political tasks and functions assigned to the civilian occupation authorities, the financial and economic ones were also important, which concerned the restoration of strategically useful sectors of the local economy for the immediate use of its resources for military needs and the establishment of a mechanism of collecting taxes and fees from the local population. In the context of considering the problem of the occupation authorities specifics deploying their tax system during the wartime, when the principles of the tax system construction were completely shifted in favour of the fiscal interests of the conquering country, the local population was considered as free labour, being forcibly deprived not only of a material wealth, the local population was made to work physically in the form of natural duties (a compulsory enlistment).

The Analysis of Recent Researches. In modern Ukrainian historiography, the problems of the Russian occupation authorities, organizing natural duties in Western Ukraine during World War I, were mentioned only briefly by the Ukrainian historians in the context of general works, researches on the socio-economic situation of the local population during the Russian civil administration. In particular, these are the works of I. Baran (Baran, 2009), K. Kondratiuk (Kondratiuk, 2006 - 2007), I. Lozynska (Lozynska, 2017), the articles by O. Mazur and I. Pater, (Mazur \& Pater, 2007, pp. 48-49), O. Reyent and I. Pater (Reyent \& Pater, 2006, p. 503).

The works of the Ukrainian researchers should be singled out, in particular, the works of P. Korinenko, V. Tereshchenko, V. Starka, and A. Kydaniuk (Korinenko, Tereshchenko, Starka \& Kydaniuk, 2016, pp. 64-65) and S. Orlyk (Orlyk, 2017; Orlyk, 2018, pp. 477-484), who considered the issue of natural duties in the occupied territories of Western Ukraine during World War I in special researches on the general problems of taxes, fees collection and other non-tax payments of the local population, organized by the Russian occupation authorities in these occupied territories. At the same time, in the domestic historiography the problems of natural duties, organized by the German occupation administration in Eastern Galicia during World War II were covered in the researches of the domestic historians: A. Bolianovskyi (Bolianovskyi, 1998), O. Klymenko and S. Tkachov (Klymenko \& Tkachov, 2013), in the monographs of K. Kurylyshyn (Kurylyshyn, 2010) and V. Starka (Starka, 2019).

Taking into consideration the above-mentioned analysis of the historiography of the problem, it should be noted that there was not carried out a special study of the problem of introduction and organization of natural duties by the Russian occupation authorities in the occupied territories of Eastern Galicia and Northern Bukovyna during World War I.

The purpose of the article is to study the mechanism of establishment and organization of natural duties by the Russian occupation authorities in the occupied territories of Eastern 
Galicia and Northern Bukovyna during World War I and the attitude of the local population to the problem of performing these natural duties.

The Statement of the Basic Material. During World War I the entry of the Russian troops into Eastern Galicia and Northern Bukovyna led to the deployment of their civilian occupation administration in the rear of the occupied territories by creating a Provisional Military Governor-General with a division into provinces and counties. By Subparagraph " $u$ " of Paragraph 22 of the "Temporary Provisional Regulations on the Management of the Regions of Austria-Hungary Occupied by the Law of War", approved by the order of the Supreme Commander of the Russian Army of July 3, 1916 №895, the Galician-Bukovynian Military Governor-General was authorized "to to establish the types of natural duties and to involve the local population into natural duties performance in the order, specified in the mandatory regulations" (Temporary regulation, 1916). For their part, governors, mayors, and county chiefs had to ensure compliance with these mandatory regulations and to be guided in their work by the "principal duty" to assist by all means at their disposal to meet the needs of the army and to facilitate relations between the army and the local population (CSHAUK, f. 722, d. 2. c. 6, p. 1).

Taking into account the above-mentioned power of the civilian bodies of the Russian occupation authorities in terms of establishing and organizing natural duties, it should be noted that the military occupation authorities also functioned in parallel in the occupied territories, whose orders had to be carried out first. Thus, in particular, in Paragraph 1 of Article 10 of the Rules "About the areas. On areas where martial law was declared" it was stated that the commanders of the armies were authorized to use the work of the local population by "involvement in work to achieve the goals of the war" (About the areas, 1892, pp. 479-480). In Article 16 of the same Rules it was stated that in the districts under the jurisdiction of the Commandant or the Head of the Precinct, all civil authorities and local residents "must obey (their - S. O. and M. A.) requirements and orders unquestioningly", even providing "hourse-drawn carts, as well as the supply of provisions, a group of labourers and means of transportation" (About the areas, 1892, pp. 480-481). At the same time, the military road and transport department, which was the part of the Department of Military Communications of the Russian Army's Front, was to supervise "the construction of new roads and dirt roads, as well as the maintenance of communications in the entire area under the Commanderin-Chief of the armies" (Changes and additions, 1916, p. 15). Such provision, of course, was carried out with the broad involvement of the local population in the form of natural duties. In addition to road work, to meet the needs of the troops there were the following types of heavy natural duties: 1) earth work and construction work related to the reconstruction of fortifications; 2) logging for military purposes and for heating; 3) reconstruction of the damaged railway line; 4) weapon cleaning, etc.

Representatives of the civil occupation authorities - heads of counties - proposed to expand the list of a mandatory natural duties, which would provide: repair of dirt country roads and paths, dams, locks and dikes, especially during spring and autumn floods; garbage removal and streets and squares cleaning, primarily, in settlements where the troops were stationed; supply of urgent letters and packages for officials of civilian institutions; night guard of a town property and the Orthodox churches; transportation of firewood for heating of the Russian administrative institutions and apartments where the military lived, etc. (SAChR, f. 27 , d. 1 , c. 43 , pp. $18-26,28-28$ v.)

The local adult population aged 17-54 was involved in the performance of natural duties, but adolescents from the age of 12 and people over the age of 54 were hired for separate jobs. 
For instance, in October 1916, the head of the ammunition depot appealed to the head of Chernivtsi district and "asked to take measures" to "deliver" him about a hundred of workers, they could be "teenagers and girls, who were 12 years old". The head of the ammunition depot asked not to send the old ones "as it used to be" (SAChR, f. 505, d. 1, c. 13, pp. 116-116 v.)

In the letters to the governors, the Russian county chiefs complained about the lack of the required working male population of a certain age, also acknowledging that due to the "small number of horses among the population and its devastation from the hostilities, etc., natural duties will be extremely burdensome for the population" (SAChR, f. 27, d. 1, c. 43, p. 18). In addition, people were afraid to go to work in those areas, which were near the front line.

The main organizers of the process of performing natural duties were county chiefs, who kept records of people, who could work, and distributed those people to work according to the military and civilian orders (SALR, f. 905, d. 1, c. 110, pp. $127-127 \mathrm{v}, 177$ ). Local civilian police and county bailiffs were involved into coercive measures organization (SAChR, f. 27, d. 1, c. 43, pp. 20-21, 25v.). However, under war conditions, the military and civilian occupation authorities often acted inconsistently, and conflicts arose over the priority of involving the local population into performing natural duties at those or other types of work. In particular, the representatives of military units often took local residents and their hourse-drawn carts to strengthen military positions without notifying the local civilian administration (SAChR, f. 505, d. 1, c. 13, p. 592).

It should be noted that for the use of the local population's labour in the form of natural duties, the occupation authorities had to pay a certain sum of money in cash, approved by the governor. For instance, in November 1916 for the performance of labour duties in Chernivtsi district there was the following payment: adult men were paid from 1 ruble up to 2 rubles per day; teenagers - from 50 kopicks up to 75 kopicks, women - from 70 kopicks up to 1 ruble 25 kopicks per day; owners of two horse-drawn carts - from 4 rubles up to 5 rubles per day; owners of one horse-drawn carts - from 2 rubles 50 kopicks up to 3 rubles per day (SAChR, f. 505, d. 1, c. 13, pp. 592-593). Such amount of payment was quite symbolic. In some cases, the amount of wages was set not for the day of work, but it depended on the weight of cargo transported and the distance over which the transportation was carried out. Such salaries were set by the Department of State Property at Galicia-Bukovyna Military Governor-General's Office in cases of payment for natural duties related to the use of a horse-drawn cart for transporting firewood from the forest to the city of Chernivtsi (SAChR, f. 505, d. 1, c. 13, pp. 951-951v.).

If the customers were military units, they had to pay the money directly to the local population, who performed natural duties, or give the money under the requisition receipt to the head of the county, who later made the final settlements with the people (SAChR, f. 505, d. 1, c. 13, p. 577; SAChR, f. 966, d. 1, c. 1, p. 127). In addition, during the use of the local population's labour at trench and road work, the population was given a meal in accordance with the norms established in the "Food Table", approved by the resolution of the Chief Office of Army Supply of the South-Western Front. In particular, "Food Table", approved on May 1, 1916, provided three types of the daily norm of food for one worker:

type № 1 - it cost 40,335 kopecks, including meat or fish for 14,875 kopicks. (this type of a daily food norm was used once a week);

type № 2 - 35,109 kopicks (this type of a daily food norm was used twice a week);

type № 3 - 33,124 kopicks (this type of a daily food norm was used three times a week) (SAChR, f. 505, d. 1, c. 13, pp. 597-599). 
Of course, such a calculated daily food norm "idyll" was disrupted by a rapid retreat or advance of the troops, when during the earth work the local labour was used in a chaotic and uncontrolled manner, mostly without any payment or, at best, with the provision of requisition receipts of a subsequent payment during indefinite term.

The use of a horse-drawn cart of the local population was problematic for the Russian occupation authorities. All cattle and their owners were registered by the heads of counties, but with each passing month there was a decrease in these indicators. Low wages, intensive and ruthless use of animals and carts for heavy work caused almost a complete destruction of the carts. These factors made people get rid of horses (SAChR, f. 505, d. 1, c. 13, p. 592). Lack of fodder was also one of the reasons for the reduction of the number of farm horses, as hay and fodder grain were confiscated by the quartermaster's detachments from the peasants by forced purchases and requisitions for the needs of the army (Orlyk, 2019).

This state of affairs endangered the implementation of the necessary military transportation, "unsystematic and improper use of horse-drawn carts, caused a direct damage to military purposes, caused a number of complaints from the local population and drew attention of the Supreme Commander" (CSHAUK, f. 363, d. 1, c. 67, p. 537). Therefore, in February 1915, a telegram was sent to the Governor-General of Galicia-Bukovyna, forbidding all military units to use horse-drawn carts of the local population without a prior agreement with the civil authorities (heads of counties or township and municipal officials). It was emphasized that payments for the use of horse-drawn carts, taken from the local population, should be made in cash immediately after the end of the work, and only in some cases it was allowed to write out receipts (CSHAUK, f. 363, d. 1, c. 67, pp. 537-537v.). This procedure concerned not only the use of horse-drawn carts, but also the use of a human labour resource.

Therefore, in compliance with the above instructions, military units were forced to apply to the heads of counties with appropriate written requests, indicating the desired number of people and horse-drawn carts, where and what kind of work they should be sent to (Orlyk, 2018, pp. 478-479).

In Lviv, the situation with the use of horse-drawn carts had some signs of sabotage by the magistrate to whom the Russian civil administration entrusted to organize natural duties. Lviv mayor repeatedly complained about the magistrate to the Military Governor-General, informing him that "the magistrate evaded the mayor's orders in all respects concerning the use of horse-drawn carts by giving excuses for their absence in sufficient numbers, and the mayor's office had to keep on repeating the orders" (Report on the Lviv city administration, 1916, p. 10).

There were frequent cases when local residents evaded the instructions of the local occupation administration in all possible ways, they did not come to work or left work without permission and hid in fields and forests. Such cases were observed en masse during the defeats of the Russian troops on the fronts. For instance, in June 1917, the Russian chief of the military unit of Army VIII informed the Regional Commissioner of Galicia and Bukovyna about the results of the activities of the "investigatory section on the conflict between soldiers and locals in the village of Chahor of Chernivtsi district". In the protocol it was stated that the military were unable to return the peasants to road and other work because "one illiterate policeman cannot gather them for carrying out army orders, as a result the interests of the army suffer, and the county commissioner has not yet taken any decisive action to eliminate this disorder". Therefore, the Army Committee of Army VIII proposed "to take more decisive measures towards the local population to obey the orders of the of 
the army, ... to appoint police officers more experienced and literate in the county" (SAChR, f. 283 , d. 1 , c. 238 , pp. 235-235v.).

In order to strengthen labour discipline during the performance of natural duties by the local population, the commanders of the Russian armies, duplicating the mandatory decrees of the Military Governor-General, issued their own threatening decrees. The main emphasis in these regulations was on the types and forms of responsibility, which should have prevented leaving any work without permission, "as well as to prohibit the refusal to go to this work". The Decree stated that violators of these requirements would be sentenced to "imprisonment for up to 3 months or a fine of up to 3000 rubles" (SALR, f. 905, d. 1, c. 110, p. 323; SAChR, f. 958 , d. 1, c. 17, p. 13). Therefore, the heads of counties, who were authorized to bring such violators to justice, massively issued decrees on the application of administrative sanctions (Orlyk, 2018a, pp. 313-314). At the same time, fines of up to 50 rubles were mostly imposed, and only in some cases the officials resorted to arrests, as it was not profitable for the occupation authorities to detain workers under conditions of a critical absence of labour force.

The Russian authorities were ruthless not only to the population of the occupied territories, but also to their own subjects. It is known that peasants from the Ukrainian provinces (including Podil and Kherson, which were the part of the Russian Empire) were forcibly involved into road work in the occupied territories of Galicia. In the places where the workers stayed, they were taken care of by the heads of the counties. In this regard, the head of Brody County informed Ternopil Governor of the lack of workers on road construction, the critical lack of fodder for horses, emphasizing also that the workers, who arrived, were poorly dressed and did not have any winter footwear (SALR, f. 905, d. 1, c. 110, p. 190).

It should be noted that under conditions of the hostilities (retreat, offensive of troops) the exploitation of the local population in the form of a natural (mostly labour) duties to do some work for the army was practised not only by the Russian occupation forces, but also by the Austrian authorities, who at that time de jure and de facto were considered the legitimate authority in Eastern Galicia and Northern Bukovyna. Most often, natural duties were associated with the construction and strengthening of military fortifications, where there was widely used free labour of the local population with their own tools, draft cattle, horse-drawn carts, etc. (Kondratiuk, 2006-2007, p. 617; Reyent \& Pater, 2006, p. 503).

During World War II, as a result of a rapid German offensive to the recently annexed territories of Eastern Galicia and Northern Bukovyna by the Soviet Union, these western Ukrainian lands found themselves in the rear of the German occupation forces for several years. In August 1941, an administrative territorial unit was created in this territory - the district (province) of Galicia with its center in Lviv, which was the part of the General Province, which was formed in October 1939 in the central-eastern part of the Polish state with an administrative center in Krakow. The researches of the Ukrainian historians, who studied the socio-economic situation of the Western Ukrainian population during World War II - A. Bolianovskyi (Bolianovskyi, 1998), O. Klymenko and S. Tkachov (Klymenko \& Tkachov, 2013), K. Kurylyshyn (Kurylyshyn, 2010) P. Korinenko, V. Tereshchenko, V. Starka, A. Kydaniuk (Korinenko, Tereshchenko, Starka \& Kydaniuk, 2016, pp. 64-65; Starka, 2019) - testify that the German occupation authorities also made extensive use of the mechanism of collecting natural duties from the local population of Eastern Galicia and Northern Bukovyna, which remained under occupation for both military and civilian purposes. The most common natural duties levied by the German occupation authorities on the local population were "sharvark duties" and "forshpany". In particular, "sharvark duties" 
included repairing and maintaining roads (for example, clearing snow, draining work, getting rid of roadside weeds, etc.). With this purpose, the occupation authorities initiated "street days", "road days" and "road weeks" (Korinenko, Tereshchenko, Starka \& Kydaniuk, 2016, p. 140). "Forshpany" was a kind of a natural duties of the local population, who owned horsedrawn carts, which they had to use to transport goods at the request of a representative of the occupation administration. The use of horse-drawn carts (forshpany) was paid according to the established rates. In particular, in Prykarpattia, for one day of work the owner of the cart received: for a single-horse cart - 9-12 zl., and for a two horse-drawn cart - $15-18 \mathrm{zl}$. (Starka, 2019, p. 266). Those, who evaded natural duties, were the subject to heavy fines or imprisonment with the possibility of being sent to a forced labour camp.

The Conclusions. Thus, the natural duties imposed by the Russian occupation authorities during World War I were a heavy burden to the local population of Eastern Galicia and Northern Bukovyna, bankrupt and devastated by war. The natural duties were one of the elements of the financial policy of the country-occupant. Extremely difficult, especially for women and adolescents, were the natural duties in the form of trench work, deforestation, restoration of rail and land routes, etc. The natural duties were extremely difficult for livestock owners, as a result of which the local population was forced to get rid of horses, which negatively affected the quality of agricultural work and worsened the level of food supply in the region. At the same time, the Russian occupation authorities practised paying low salary, which was not even always paid. The performance of the natural duties by the local population was coercive, which was exacerbated by the imposition of severe liability in the form of high fines or imprisonment (arrest). At the same time, it was advantageous for the occupation authorities to exploit the local population, because during the war the exploitation allowed them to save significant financial resources.

Having done a comparative analysis of the occupation authorities actions, established in the lands of Eastern Galicia and Northern Bukovyna, - the Russian occupation authorities (during World War I) and the German occupation authorities (during World War II), we concluded that in both cases the local population was subjected to severe coercion measures and had to work in the interests of the occupation military forces and civilian authorities. According to the author, the whole set of the natural duties should be divided into two groups, taking into account the peculiarities of establishment. The first group included military occupation natural duties, which were performed during active and positional hostilities to build fortifications, to restore damaged bridges, land roads and railways, etc. The military occupation natural duties were usually established by the military authorities (including the military commandant's office). The second group included civil occupation natural duties, which were introduced in the rear areas, where the civil occupation authorities, who by their decrees and orders determined the list and procedure for collection of natural duties aimed at the needs of rear military units and support the necessary activities of the occupied territories (construction and restoration of land roads and bridges, construction of rear fortifications, road cleaning, deforestation, sawing and transportation of logs of wood, removal of sewage and cleaning in settlements, the use of horse-drawn carts for the transportation of goods and cargo for the needs of the troops and the civilian occupation authorities (as well as the transportation of confiscated products during quartermaster procurement and requisitions), night guard to perform security functions, etc.). The first group of a natural duties was performed free of charge, and the second one - included the payment for the work performed in accordance with established tariffs, which were not adequate because they did not correspond to the cost of resources spent on labour and means. 
In general, under conditions of both world wars, the process of introduction of natural duties for the needs of both the army and the civilian occupation authorities by the conquering countries the Russian Empire and the Nazi Germany - was characterized by many common features.

Therefore, further research requires the establishment and collection of taxes, fees and other non-tax payments from the population of Western Ukraine by various occupation regimes during the First and Second World War I and World War II. In our opinion, a comparative analysis of these problems will be especially important and perspective for scientific consideration.

Acknowledgement. We express sincere gratitude to all members of the editorial board for consultations provided during the preparation of the article for printing.

Funding. The authors received no financial support for the research, authorship, and/or publication of this article.

\section{BIBLIOGRAFY}

Baran, I. V. (2009). Vplyv boiovykh dii na stanovyshche mist i sil Skhidnoi Halychyny na pochatku Pershoi svitovoi viiny [The impact of hostilities on the situation of cities and villages in Eastern Galicia at the beginning of World War I]. Visnyk Natsionalnoho universytetu "Lvivska Politekhnika", (652), 46-55. [in Ukrainian]

Bolianovskyi, A. (1998). Sotsial'nyy aspekt hitlerivs'koho "novoho poryadku" v Halychyni u 1941 - 1944 rokakh [The Social Aspect of Hitler's "New Order" in Galicia during 1941 - 1944]. Visnyk Lvivskoho universytetu. Seriia istorychna, (33), 186-194. [in Ukrainian].

Derzhavnyi arkhiv Lvivskoi oblasti [SALR - State Archives of Lviv region]

Derzhavniy arkhiv Chernivetskoi oblasti [SAChR - State Archives of Chernivtsi region]

Changes and additions. (1916). Izmenenija i dopolnenija statey Polozheniya o polevom upravlenii voysk $v$ voennoe vremya posledovavshie v periods 20 iyulya $1914 \mathrm{~g}$. po 1-e marta $1916 \mathrm{~g}$. [Changes and additions to the articles of the Regulation on the field control of troops in during that followed from July 20, 1914 to March 1, 1916]. Petrograd: voennaya tip. Imperatritsy Yekateriny Velikoy, 19 p. [in Russian]

Klymenko, O. O. \& Tkachov, S. V. (2013). Ukraintsi v politsii v dystrykti "Halychyna" (Ternopilskyi okruh): nimetskyi okupatsiinyi rezhym v Ternopoli ta okolytsiakh u 1941 - 1944 rr. [The Ukrainians in the Police in the Halychyna District (Ternopil District): German Occupation Regime in Ternopil and Vicinity during 1941 - 1944]. Kharkiv: Ranok NP, 600 p. [in Ukrainian]

Kondratiuk, K. (2006 - 2007). Vtraty Skhidnoi Halychyny v roky Pershoi svitovoi viiny [Losses of Eastern Galicia during World War I]. Ukraina: kulturna spadshchyna, natsionalna svidomist, derzhavnist, (15), 616-622. [in Ukrainian].

Korinenko, P. S., Tereshchenko, V. D., Starka, V. V. \& Kydaniuk, A. V. (2016). Podatky i povynnosti v halytskomu seli (kinets XVIII-seredyny XX st.) [Taxes and duties in the village of Galicia (the end of the XVIIIth - the middle of the XXth century)]. Ternopil, 200 p. [in Ukrainian]

Kurylyshyn, K. (2010). Ukrainske zhyttia v umovakh nimetskoi okupatsii (1939 - 1944 rr.): za materialamy ukrainskoi lehalnoi presy [Ukrainian Life during German Occupation (1939 - 1944): According to the Ukrainian Legal Press]. Lviv: LNNB im. V. Stefanyka, 328 p. [in Ukrainian]

Lozynska, I. (2017). Orhanizatsiya rosiys'koho tsyvil'noho upravlinnya u Halychyni (serpen'-veresen' 1914 roku) [Organization of Russian civil administration in Galicia (August-September 1914)]. Skhidnoyevropeys'kyy istorychnyy visnyk - East European Historical Bulletin, 2, 21-30. doi: https://doi.org/10.24919/2519-058x.2.101456 [in Ukrainian]

Mazur, O. Ya. \& Pater, I. H. (2007). Halyts'ka "Ruyina": sotsial'no-ekonomichne stanovyshche Skhidnoyi Halychyny (1914-1915 rr.) [Galician Ruin: The socio-economic situation of Eastern Galicia (1914-1915)]. Visnyk Natsionalnoho universytetu "Lvivska politekhnika". Derzhava ta armiya, (584), 44-52. [in Ukrainian].

About the areas. (1895). O mestnostjah, ob'yavlyayemykh sostoyashchimi na voyennom polozhenii: Zakon Rossiyskoy imperii ot 18 iyunya 1892 g. № 8757 [About the areas declared under martial 
law: Law of the Russian Empire of June 18, 1892 No. 8757]. Polnoe sobranie zakonov Rossiyskoy imperi (collection III, Vol. XII, pp. 479-483). Sankt-Peterburg, 1895. [in Russian]

Orlyk, S. V. (2017). Ekonomichne stanovysche ta podatna zdatnist' selian Halychyny i Bukovyny $\mathrm{v}$ period rosijs'koi okupatsii $\mathrm{v}$ chasy Pershoi svitovoi vijny [Economic situation and taxable capacity of villagers of Galicia and Bukovyna during the period of the Russian occupation during World War I]. Ukrainskyi selianyn - Ukrainian Peasant, 18, 93-100. [in Ukrainian]

Orlyk, S. V. (2018). Finansova polityka rosiiskoho uriadu na okupovanykh terytoriiakh Halychyny $i$ Bukovyny $v$ period Pershoi svitovoi viiny (1914 - 1917 rr.) [Financial policy of the Russian government in the occupied territories of Galicia and Bukovyna during World War I (1914 - 1917)]. Bila Tserkva: vydavets Pshonkovsky O. V., 716 p. [in Ukrainian]

Orlyk, S. V. (2018a). Finansova polityka rosiys'koho okupatsiynoho rezhymu v Halychyni ta Bukovyni v roky Pershoyi svitovoyi viyny (1914 - $1917 \mathrm{rr}$.) [Financial policy of the Russian occupation regime in Galicia and Bukovyna during World War I (1914 - 1917)]. (Doctoral tesis). Kyiv, 806 p. [in Ukrainian]

Orlyk, S. V. (2019). Zakupivli ta rekvizytsiyi u selyan Skhidnoyi Halychyny y Bukovyny pid chas rosiys'koyi okupatsiyi u roky Pershoyi svitovoyi viyny [Economic situation and taxable capacity of villagers of Galicia and Bukovyna during the period of the Russian occupation during World War I]. Ukrayins'kyy selyanyn - Ukrainian Peasant, 21, 34-40. doi: https://doi.org/10.31651/2413-81422019-21-34-40 [in Ukrainian]

Report on the Lviv city administration. (1916). Otchet po Lvovskomu gradonachalstvu (s 21 avgusta po den evakuatsii Lvova 7 iyunya 1915 g.) [Report on the Lviv city administration (from August 21 to the day of the evacuation of Lviv on June 7, 1915)]. Prilozhenie k otchetu voennogo general-gubernatora Galitsii № 5. Kiev, 18 p. [in Russian]

Reyent, O. P. \& Pater, I. H. (2006). Svitova viyna 1914 - 1918 rr. i ukrayins'ke selyanstvo [World War I 1914 - 1918 and the Ukrainian peasantry]. Istoriya ukrayins'koho selyanstva (Vol. 1, pp. 473-524). Kyiv: Naukova dumka. [in Ukrainian]

Starka, V. V. (2019). Povsyakdenne zhyttya zakhidnoukrayins'koho sela v umovakh suspil'nykh transformatsiy 1939 - 1953 rr [Everyday life of the Western Ukrainian village under conditions of social transformations of 1939 - 1953.]. Ternopil: Osadtsa Yu.V., 550 p. [in Ukrainian]

Tsentralnyi derzhavnyi istorychnyi arkhiv Ukrainy, m. Kyiv (CSHAUK - Central State Historical Archives of Ukraine in Kyiv)

Temporary regulation. (1916). Vremennoe polozhenie. Ob upravlenii oblastyami Avstro-Vengrii, zanyatymi po pravu voyny: Prikaz Nachalnika Shtaba Verkhovnogo Glavnokomanduyushchego ot 3 iyulya $1916 \mathrm{~g}$. [Temporary regulation on the management of areas of Austria-Hungary occupied by the law of war: Order of the Chief of Staff of the Supreme Commander of July 3, 1916]. Rossiya. Shtab Verkhovnogo Glavnokomanduyushchego (1914 - 1917). Prikazy nachalnika Shtaba Verkhovnogo glavnokomanduyushchego za 1916 god, part 1. [in Russian]

The article was received on January 30, 2020. Article recommended for publishing 26/08/2020. 